\title{
Sociobiology
}

RESEARCH ARTICLE - ANTS

\section{The Effect of Nest Size and Species Identity on Plant Selection in Acromyrmex Leaf-Cutting Ants}

\author{
LE JOFRÉ ${ }^{1}$, Al MEDINA ${ }^{1}$, AG FARJI-BRENER ${ }^{2}$, MM MOGLIA $^{1}$ \\ 1 - Universidad Nacional de San Luis, San Luis, Argentina \\ 2 - Laboratorio de Investigaciones en Hormigas (LIHO), INIBIOMA-CONICET-Universidad Nacional del Comahue, Rio Negro, Argentina
}

\begin{tabular}{|c|c|}
\hline \multicolumn{2}{|l|}{ Article History } \\
\hline \multicolumn{2}{|l|}{ Edited by } \\
\hline \multicolumn{2}{|c|}{ Ricardo Solar, UFMG, Brazil } \\
\hline Received & 26 March 2018 \\
\hline Initial acceptance & 20 June 2018 \\
\hline Final acceptance & 20 July 2018 \\
\hline Publication date & 02 October 2018 \\
\hline
\end{tabular}

\section{Keywords}

Acromyrmex, ant nests, Chaco, foraging behavior.

\section{Corresponding author}

Laura Elizabeth Jofré

Universidad Nacional de San Luis

Área de Zoología

Ejercito de los Andes no 950,

D5700HHW, San Luis, Argentina.

E-Mail: lauelijofre@gmail.com

\begin{abstract}
Leaf-cutting ants are key organisms because their role as primary consumers and potential agricultural pests. However, their foraging ecology was mostly studied as response of extrinsic factors such as climate and plant species traits. We evaluated the effects of intrinsic factors (i. e., nest size and species identity) on the foraging behavior in two species of Acromyrmex Mayr leaf-cutting ants. While large and small nests of $A$. lobicornis Emery showed similar feeding behavior, small nests of $A$. striatus Roger harvested a greater percent of the plant species available in their foraging area and showed a higher level of selectivity than larger nests. We discussed some probable reasons for this pattern. Our results highlight the relevance of intrinsic factors and species characteristics to explain changes in the foraging ecology of leaf-cutting ants as colony growth.
\end{abstract}

\section{Introduction}

Leaf-cutting ants, Atta Forel and Acromyrmex Mayr, are considered the dominant herbivores of the Neotropical Region (Hölldobler \& Wilson, 1990). The workers cut, collect and carry plant fragments to the nest where they grow a symbiotic fungus, the main food source of larvae (Cherrett, 1989). These ants forage on a large number of plant species, but generally most of their diet consists of a few selected ones (Rockwood \& Hubbel, 1987; Franzel \& Farji-Brener, 2000). There are external and intrinsic factors that can influence the diet composition of leaf-cutting ants. On one hand, the number and amount of plant species harvested depend on their diversity, nutritional quality, chemical/physical defenses, abundance and spatio-temporal distribution (Nichols-Orians \& Schultz, 1990; Franzel \& Farji-Brener, 2000; Farji-Brener, 2001; Wirth et al., 2003; Lanan, 2014). However, diet composition also depends on intrinsic characteristics of the colony, such as size and age of the nests (Wetterer, 1994; Kost et al., 2005). While the external factors that modeled leaf-cutting ant diet has been largely studied (see a review in Hölldobler \& Wilson, 2011), those related with the colony status and species identity remain less understood.

Some authors suggest that the foraging ecology of small or juvenile colonies differs from large or mature colonies (Wetterer, 1994; Kost et al., 2005). For example, in some Atta species small colonies forage mainly herbs near their nests, while larger colonies forage more distant woody species (Wetterer, 1994; Kost et al., 2005). However, most of these comparisons between trophic behavior and nest size have been made on the genus Atta, being less known for Acromyrmex. Moreover, species characteristics such as their worker density and the complexity of the trail system may also influence on their foraging ecology. We complemented this information analyzing whether Acromyrmex species also change their diet as they growth. The knowledge whether small and adult leaf-cutting ant colonies differ in their foraging ecology will provide theoretical and applied useful information. First, this info will help to better understand the relationship between the ontogeny of herbivore populations and their foraging 
preferences. Second, and because these ants are considered one of the major pests of forestry and agricultural lands, the info of how diet changes as nest growths will be vital to applied adequate management practices.

Acromyrmex striatus Emery and A. lobicornis Roger are two of the most common leaf-cutting ant species in Argentina (Farji-Brener \& Ruggiero, 1994). These species are good model to evaluate the effect of colony size and species identity on their diet because live in simpatry but differ in some characteristics. Concretely, A. lobicornis constructs nests with an external nest-mound (Farji-Brener, 2000; Bollazzi et al., 2008) that house about 10.000 workers (Jofré \& Medina, 2012) and build well defined trails to forage. In contrast, A. striatus constructs relatively smaller subterranean nests without a nest-mound, in areas of low vegetation cover and their workers forage at close distances from the nest without a defined network trail system (Boneto, 1959; Diehl-Fleig, 1995). In addition, both species consume a high percentage of species available in the environment (Armani \& Quirán, 2007; Nobua-Behrmann, 2014), and their degree of selectivity or opportunism depends on the temporal space fluctuations of the resources (Farji-Brener \& Protomastro, 1992; Pilati et al., 1997; Franzel \& Farji-Brener, 2000; Armani \& Quirán, 2007; Nobua-Behrmann, 2014). The objective of this work was to evaluate the effect of nest size and species identity on the foraging behavior of two leaf-cutting ant species. Specifically, we tested whether diet composition, plant richness, niche breadth and degree of selectivity depends on nest size, species identity and/or the interaction between them.

\section{Materials and methods}

\section{Study area}

The nests of $A$. lobicornis and $A$. striatus were randomly selected in a natural reserve of San Luis, Argentina $\left(33^{\circ}\right.$ $07^{\prime} \mathrm{S}$ y $66^{\circ} 03^{\prime} \mathrm{W}$ ). The area has 340 ha, with an average altitude of 850 amsl. The average annual temperature in January (summer) is $25{ }^{\circ} \mathrm{C}$ and $9{ }^{\circ} \mathrm{C}$ in July (winter); the mean annual rainfall is about $600 \mathrm{~mm}$ (Del Vitto et al., 1994). The vegetation is represented by species belonging to the Phytogeographic Province of Chaco, Chaqueño Serrano District (Cabrera \& Willink, 1980). This nature reserve was affected by overgrazing, fire, and logging. Due to these disturbances native plant species typical of Chaco Serrano as well as exotic species are common in the area (Del Vitto et al., 1994; Chébez, 2006). The dominant native species are Lithraea molleoides, Prosopis caldenia, Vachellia caven, Celtis ehrenbergiana, Briza subaristata, Eragrostis lugens, Bouteloua curtipendula, Schizachyrium plumigerum, Bothriochloa springfieldii mixed with exotic species such as Rosa rubiginosa, Ulmus sp., Robinia pseudoacacia and Cynodon sp. (Del Vitto et al., 1994; Chébez, 2006).
Nest size

We consider nest size as a proxy of colony growth because for leaf-cutting ants, nests size is considered a good estimator of the colony age (Fowler, 1977; Vieira-Neto et al., 2016). Colony size influences the number and caste morphology of workers as well as the distance where the colony search for resources (Hölldobler \& Wilson, 2011). We consider the nesting characteristics of each species to separate small from large nests: the size of nest-mound in $A$. lobicornis and the number of entrance holes in A. striatus. These measurements were carried out in a total of 28 nests (14 of each species). To differentiate small from large nests in A. lobicornis we used the criteria described in Farji-Brener et al. (2003), where small colonies were those with nest-mound diameters $(\varphi) \leq 70 \mathrm{~cm}$ and large with $\varphi \geq 100 \mathrm{~cm}$. For $A$. striatus, Diehl-Fleig (1995) states that number of entrance holes of nest are good estimator of the age of colony. Using this criterion, small colonies were divided into those with up to 2 entrance holes and large colonies with more than 5 entrance holes. Consequently, each size category was composed of 7 nests for each species.

\section{Diet composition and resource availability}

During the summer of 2013-2014 (December- March), the season of higher ant activity and plant abundance, we determined the diet composition and resource availability in 28 colonies of both species of Acromyrmex. Diet composition was determined by collecting of the vegetal material carried by the workers during 5 minutes in the hours of maximum foraging activity. This collection was carried out to complete 8 samples per nest on two non-consecutive days (a total of 224 diet samples for both species). The collected material was placed in paper bags and taken to laboratory for analysis under a stereo microscope. This procedure is widely employed to determine diet composition and foraging preferences of leaf cutting-ants (Pilati et al., 1997; Franzel \& Farji-Brener, 2000; Farji-Brener 2001; Behrmann, 2014; Farji-Brener \& Tadey, 2017). Each fragment present in the diet was identified at the plant species or genus level with the help of a reference collection of plants from the study site. We identified of 6250 plant fragments carried by A. lobicornis and 2169 by A. striatus, (approximately $85 \%$ to species level) since ant workers collect entire leaves or parts of flowers and fruit. Subsequently, the relative frequency of each plant species in the diet $\left(\mathrm{d}_{\mathrm{i}}\right)$ in each colony was estimated as the number of fragments per plant species divided the number of total carried fragments.

In the same sampling period, the resource availability $\left(o_{i}\right)$ was determined within the foraging area. Circular foraging areas were estimated using an average length of foraging trails, which represent the radius of the foraging circumference area. In $A$. striatus the average distances 
traveled by the forage workers were used, since this species does not build cleared trails. Therefore, the forage areas were estimated in $1520 \mathrm{~m}^{2}$ for A. lobicornis and $78.5 \mathrm{~m}^{2}$ for A. striatus. To estimate the availabity of plant resources for each colony we randomly located 10 square plots within each foraging area following the methodology of Hays et al. (1981). Five squares of $1 \mathrm{~m}^{2}$ (subdivided in $10 \times 10$ $\mathrm{cm}$ ) were used to determine the frequency of herbs and 5 squares of (subdivided in $20 \times 20 \mathrm{~cm}$ ) to determine the frequency of woody species. The relative frequency of each species per $\mathrm{m}^{2}$ was estimated as the number of subdivisions where the species was present divided the number of total subdivisions. The mean value of the 10 squares was used to determine the relative frequency $\left(\mathrm{o}_{\mathrm{i}}\right)$ of each plant species on the foraging area.

\section{Niche breadth and foraging selectivity}

The relative frequencies of each plant species in foraging area $\left(o_{i}\right)$ and their relative frequency in the diet $\left(d_{i}\right)$ were used to estimate the trophic breadth and ant selectivity for each plant species. Feinsinger's niche breadth index (PS, Feinsinger et al., 1981) was used to evaluate the trophic breadth. This index estimates (in \%) the overlap's degree between the frequencies' distribution of the resources in the diet with the distribution of frequencies of resources in foraging area as:

$$
P S=\left[\sum \min \left(o_{i}, d_{i}\right) \cdot 100\right]
$$

Where $o_{i}$, is the relative frequency of each plant species in foraging area, and $\mathrm{d}_{\mathrm{i}}$ represent the relative frequency of each plant species in the diet. The PS index takes values between 0 and 100 , being the minimum trophic breadth or specialism and maximum trophic breadth or generalism, respectively (Feinsinger et al., 1981).

To determine which plant species was selectively consumed we used the Ivlev index (1961):

$$
I S=\frac{d_{i}-o_{i}}{d_{i}+o_{i}}
$$

The IS index takes values between -1 and 1 being maximum rejection or maximum selectivity, respectively. Values close to -1 indicate that the species is in a lower proportion in the diet than its availability in the environment (rejection). Values near 0 indicate that the proportion of species in the diet and in the environment is similar (opportunism). While values close to one 1 indicate that the species is in a higher proportion in the diet than in the environment (selectivity). We subjectively consider that a plant species was consumed selectively when it IS was $\geq 0.7$. Therefore, the percentage of the diet composed of species consumed selectively was calculated summing the percent of all the plant species in the diet with an IS $\geq 0.7$ (Appendix 1 and Appendix 2).
Data analysis

We calculated the species richness in the diet and in the foraging area for each nest size. These data were compared between nest sizes of each species using either independent t-tests or its non-parametric equivalent as appropriate. Data were analyzed using $\mathrm{R}$ program v.3.2.2 (R Core Team, 2015). In addition, plant species from diet and resources were separated into herbaceous and woody species, estimating the average percentage collected in nests of different sizes. To determine the dependence of nest size and the presence in the diet of herbaceous and woody species we used a Chi-square test.

To compare the niche breadth (PS) and percentages of the selectively foraged species (IS $\geq 0.7$ ) between the nest sizes of each species we used a two-way ANOVA for each response variable. Nest size and ant species were considered fixed factors. ANOVA assumption was checked. Post-hoc comparisons were performed using Tukey tests. Data were analyzed using Statistica $8.0 \AA$.

Finally, Permutational multivariate analysis of variance (PERMANOVA), with 999 permutations, was carried out for analyze on the effect of nest size and ant species identity on diet composition. Data were analyzed using $\mathrm{R}$ program v.3.2.2 (R Core Team, 2015).

\section{Results}

Plant richness and diet composition

Acromyrmex striatus and A. lobicornis used a large portion of the available plant resources but showed some differences depending on the nest size. In $A$. striatus, small nests harvested 36 of 83 plant species available in their foraging area (43\%). The most frequently harvested plant species were Celtis ehrenbergiana, Cynodon sp., Tripodanthus flagellaris, Oxalis sp. and Vachellia caven which represents $62 \%$ of the species consumed by small nests (Appendix 3). Conversely, large nests of $A$. striatus harvested only 10 of 51 plant species available in their foraging area (20\%). The most harvested plant species were Cynodon sp. and Prosopis caldenia representing $85 \%$ of their total diet (Appendix 3). Accordingly, the species richness consumed per nest was higher in small nests $(9 \pm 4)$ than in large nests $(4 \pm 1),(\mathrm{W}=1, p=0.003)$. On the other hand, the areas where the small nests were found showed a greater mean number of species available $(\mathrm{t}=-2.7, \mathrm{df}=11, p=0.02$, see Fig 1$)$. The percentage represented by herbaceous and woody species in the diet of $A$. striatus showed similar values according to the size of their nests. Both small nests and large nests collected a larger proportion of woody species (woody: 48.5\% small nests and 66\% large nests). While the herbaceous species reached values between 30 and $35 \%\left(\chi^{2}=2.5\right.$, df $=1, p=$ 0.1 ; Fig 2). The foraging areas showed a high percentage of woody plants in both, large and small nests $\left(\chi^{2}=1.4, \mathrm{df}=1\right.$, $p=0.2$, Fig 2) (see Table 1). 
Table 1. Summary of the main results of the species richness consumed, species richness in the foraging area, niche breadth (PS) and percentage of species consumed selectively for small nests and large of A. lobicornis y A. striatus. The values correspond to the mean $\pm \mathrm{SD}$. Different letters in the rows indicate statistically significant differences $(p<0.05)$ for each species of leaf-cutting ants.

\begin{tabular}{lcccc}
\hline & \multicolumn{2}{c}{ Acromyrmex striatus } & \multicolumn{2}{c}{ Acromyrmex lobicornis } \\
& Small nests & Large nests & Small nests & Large nests \\
\hline Sp. richness consumed & $9 \pm 4^{\mathbf{a}}$ & $4 \pm 1^{\mathbf{b}}$ & $14 \pm 4^{\mathbf{c}}$ & $14 \pm 4^{\mathbf{c}}$ \\
Sp. richness foraging area & $26 \pm 5^{\mathbf{a}}$ & $16 \pm 7^{\mathbf{b}}$ & $28 \pm 5^{\mathbf{c}}$ & $30 \pm 3^{\mathbf{c}}$ \\
Niche breadth (Ps) & $52 \pm 18^{\mathbf{a}}$ & $29 \pm 15^{\mathbf{b}}$ & $32 \pm 9^{\mathbf{c}}$ & $30 \pm 7^{\mathbf{c}}$ \\
$\%$ spp selec. cons. & $47 \pm 29^{\mathbf{a}}$ & $12 \pm 20^{\mathbf{b}}$ & $47 \pm 16^{\mathbf{c}}$ & $54 \pm 18^{\mathbf{c}}$ \\
\hline
\end{tabular}

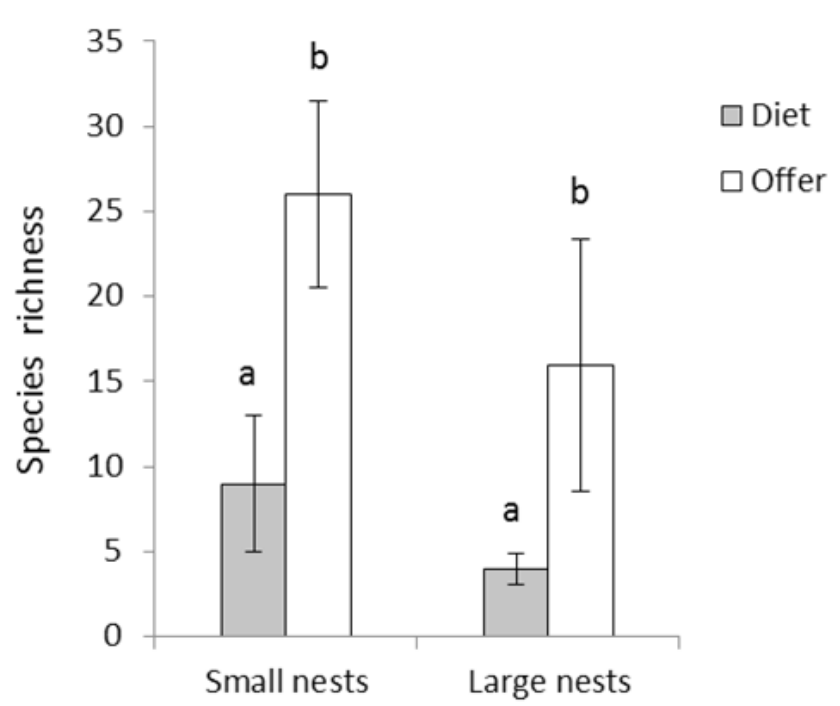

Fig 1. Average species richness $( \pm \mathrm{SD})$ in the diet and in foraging area of $A$. striatus. Different letters indicate significant statistical differences $(p<0.05)$.

In A. lobicornis, small nests harvested 49 of 82 plant species available in their foraging area $(60 \%)$. The most frequently harvested species were Celtis ehrenbergiana, Cynodon sp., Heterotheca subaxillaris, Schkuhria pinnata representing approximately $45 \%$ of the total of the diet (Appendix 4). On the other hand, large nests harvested 52 of 87 plants species available in their foraging area (60\%). The most commonly consumed vegetable items were Cynodon sp. and Rosa rubiginosa, which accounted for $28 \%$ of the total diet. The rest of the species consumed in small and large nests contributed less than $6 \%$ to the total diet (Appendix 4). The richness of plant species consumed per nest and those available in the foraging area were similar between large and small colonies (all $p>0.4$ ) (Fig 3). The percentage of herbaceous and woody species harvested by A. lobicornis was similar in the small nests (approximately $45 \%$ ), while the large nests presented higher values of woody species in their $\operatorname{diet}(60 \%$ woody vs. $30 \%$ herbaceous $)\left(\chi^{2}=4.6, \mathrm{df}=1, p=\right.$ 0.03 , Fig 4). Foraging areas showed a higher percentage of herbaceous species in both types of nests $\left(\chi^{2}=0, \mathrm{df}=1, p=\right.$ 1, Fig 4) (see Table 1). Finally, diet composition was similar between nest sizes and ant species (PERMANOVA, all $p>$ 0.40 , Table 2).

\section{Niche breadth and foraging selectivity}

The niche breadth (PS) indexes varied between nests sizes depending the ant species $\left(\mathrm{F}_{1,24}=6.3, p=0.02\right)$ (Fig 5a, Appendix 5). The PS of $A$. striatus was significantly higher in large nests $(52 \pm 18)$ than in small ones $(29 \pm 15)$, suggesting that small nests of $A$. striatus are mostly specialists. But $A$. lobicornis presented similar PS values between small nests $(32 \pm 9)$ and large ones $(30 \pm 7)$ (Table 1, Appendix 5).

The percentage of species harvested selectively varied between nests sizes depending the ant species $\left(\mathrm{F}_{1,24}\right.$ $=6.8, p=0.015)($ Fig 5b, Appendix 5). Small colonies of $A$. striatus were more selective than large ones. Small colonies selectively harvested the $47 \% \pm 29$ (mean \pm SD) of his diet, whereas large colonies only the $12 \% \pm 20$. Conversely, large and small colonies of $A$. lobicornis showed a similar percent of species harvested selectively (Table 1, Appendix 5).

Table 2. Results of PERMANOVA from nest size and ant species identity on diet composition.

\begin{tabular}{lcccccc}
\hline & Df & SS & Ms & F & $\mathrm{R}^{2}$ & $p$ \\
\hline Specie & 1 & 114281 & 114281 & 214.5 & 0.91 & 0.40 \\
Size & 1 & 117478 & 117478 & 220.5 & 0.94 & 0.40 \\
Interaction & 1 & -119623 & -119623 & -224.6 & -0.96 & 0.81 \\
Residuals & 24 & 12785 & 533 & 0.102 & 0.10 & \\
Total & 27 & 124920 & & & 1 & \\
\hline
\end{tabular}

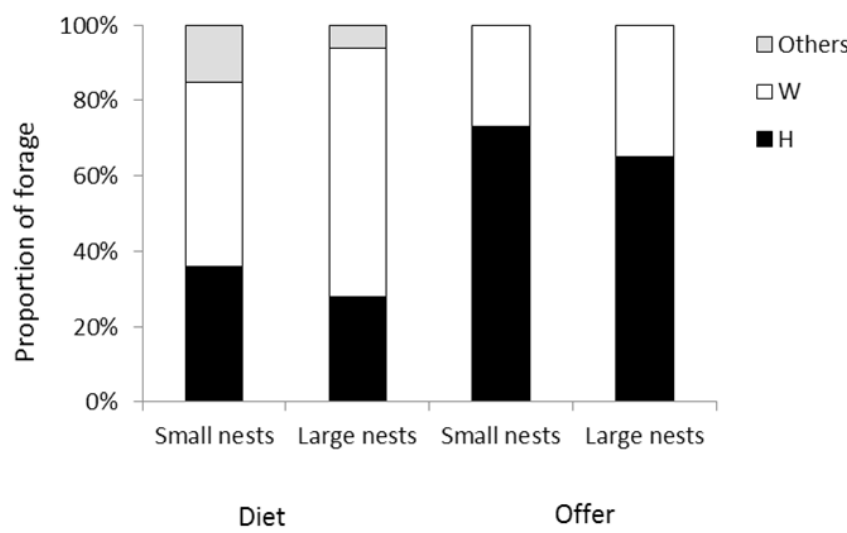

Fig 2. Relative proportion (\%) of woody (W) and herbaceous (H) species present in the diet and in the offer of small and large nests of A. striatus. Others: unidentified species in the diet. 


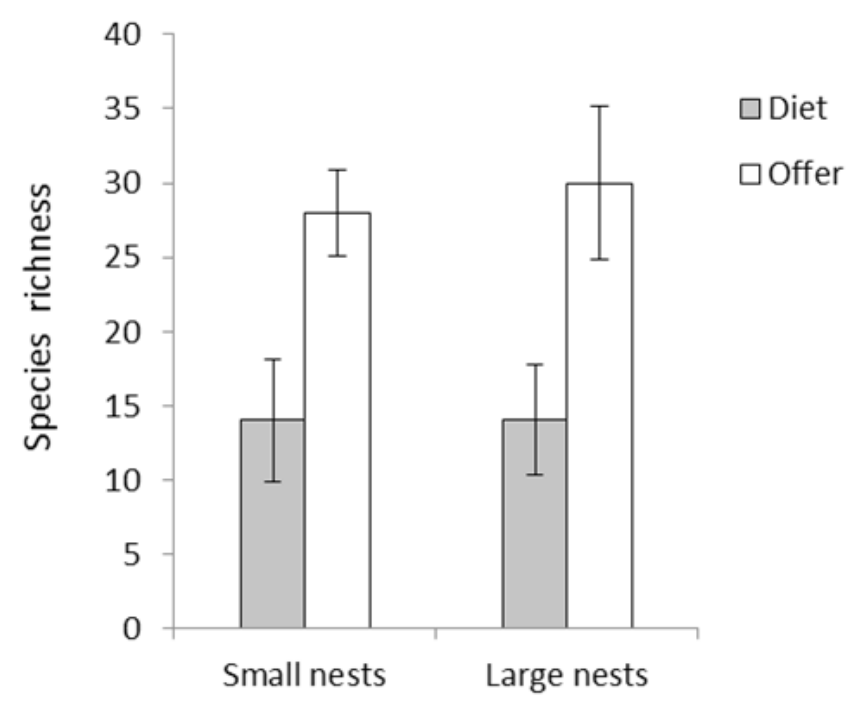

Fig 3. Average species richness $( \pm \mathrm{SD})$ in the diet and in the foraging area of A. lobicornis.

\section{Discussion}

It is known that the foraging ecology of leaf-cutting ants is affected by extrinsic factors, such as plant defense traits (Nichols-Orians \& Schultz, 1990; Wirth et al., 2003). Here we demonstrated intrinsic factors, such as nest size and species identity, can also affect the foraging patterns in this ant group. Despite that diet composition was similar among nest sizes and species identity, both species showed different foraging behaviors depending on nest size. While small and large nests of A. lobicornis showed similar number of species harvested, percent of species harvested selectively and niche amplitude, small nests of $A$. striatus showed differences between these three descriptors of foraging behavior regarding large nests. Small colonies of $A$. striatus showed higher values of niche breadth (PS $=52 \pm 18$ ) whereas their diet consisted of $47 \%$

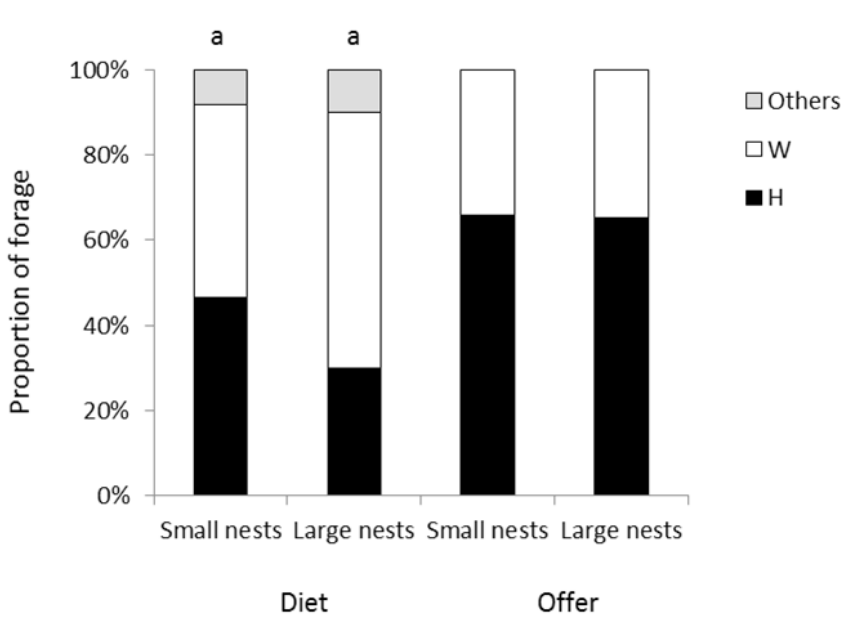

Fig 4. Relative proportion (\%) of woody (W) and herbaceous (H) species present in the diet and in the offer of small and large nests of A. lobicornis. Others: unidentified species in the diet. Equal letters indicate significant differences $(p<0.05)$.
$( \pm 29)$ of species selectively harvested, suggesting high selectivity in small than in larger nests. In other words, in $A$. striatus the selectivity and the importance of selected plant species in its diet decrease as colony growths. One possible explanation is that the higher selectivity of small nests is consequence of a low capacity to deal against chemical and physical plant defenses in earlier stages of the colony ontogeny. Future works should test this hypothesis. The great flexibility in the foraging of this ant species found in other studies may support this hypothesis, since high variability of diet may help to compensate the negative effect of chemical plant defenses on their fungi culture (Farji-Brener \& Protomastro, 1992; Nobua-Behrmann, 2014). Conversely, large and small nest of A. lobicornis showed similar niche breadth values (PS = 32 and 30, respectively) suggesting selectivity for both nest sizes (Table 1). These results are similar to those found in different regions of Argentina where A. lobicornis showed high selectivity in summer (Franzel \& Farji-Brener, 1992; Nobua-Bhermann, 2014).
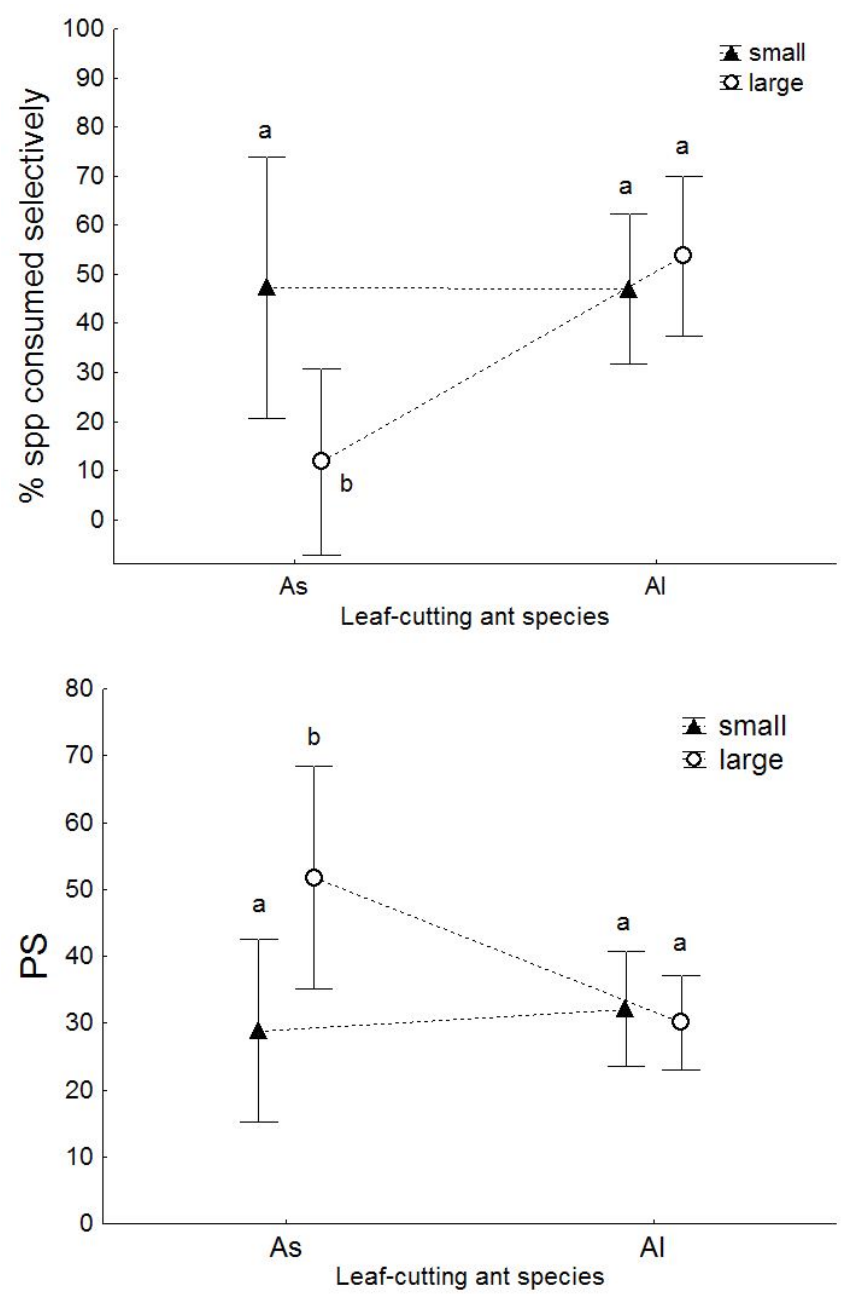

Fig 5. Graphical representation of the interaction between nest size (small and large nests) and species of leaf-cutting ants (As and Al) for the variables (a) niche breadth (PS) and (b) species consumed selectively (\%). As: Acromyrmex striatus, Al: A. lobicornis. Different letters mean statistical significant differences $(p<0.05)$. 
An open question is why $A$. lobicornis do not change their selectivity level as the colony growths. In other words, which characteristics differ between the studied species that can be associated to a change in the selectivity as nest grows in A. striatus but not in A. lobicornis. These ants have different thermal tolerance ranges that result in temporally separated foraging activities avoiding interference competition (NobuaBehrmann et al., 2017). On the one hand leaf-cutting ants have different nesting and digging behavior at the same soil temperature regimes (thermic or hyperthermic soil) (Bollazi et al., 2008). On the other hand, A. lobicornis has some typical characteristics of a dominant species, such as big colonies (Stuble et. al. 2017, Nobua-Behrmann et al., 2017). A better thermoregulation capacity and a larger worker density make A. lobicornis more ecologically dominant than $A$. striatus. This suggests that the high selectivity of $A$. striatus in the most vulnerable stages of growth can help this subordinate species to coexist with a superior competitor. Foraging selectivity involves cost and benefits. To be selective is a time and energy demanding activity, particularly costly in climatically rigorous environments such as in our sample region. However, this cost could be compensated by the nutritional quality of the selected food. We suggest that the balance between costs and benefits that stimulate the change of foraging strategy as the colony growth depends also on intrinsic characteristics of the ant species. Moreover, our results highlight the relevance of intrinsic factors to explain changes in the foraging ecology of leaf-cutting ants as colony growth.

\section{Supplementary material}

http://periodicos.uefs.br/index.php/sociobiology/rt/suppFiles/3263/0 http://dx.doi.org/10.13102/sociobiology.v65i3.3263.s2210

\section{Acknowledgments}

We thank the people who collaborated in the field samplings and the staff of the "Wildlife Conservation Center La Florida" of the province of San Luis.

\section{References}

Armani, A. \& Quirán, E. (2007). Evaluación cualitativa y cuantitativa de la oferta y cosecha de biomasa herbácea por Acromyrmex striatus Roger (Hymenoptera: Formicidae) en la provincia de La Pampa, Argentina. Gayana, 71: 203-206.

Bollazzi, M., Kronenbitter, J. \& Roces, F. (2008). Soil temperature, digging behaviour, and the adaptive value of nest depth in South American species of Acromyrmex leaf-cutting ants. Oecologia, 158: 165-175. doi: 10.1007/s00442-008-1113-Z

Bonetto, A.A. (1959). Las hormigas "cortadoras" de la provincia de Santa Fe (Géneros Atta y Acromyrmex). Ministerio de Agricultura y Ganadería. Santa Fe, Argentina, 75 p.

Cabrera, A. \& Willink, A. (1980). Biogeografía de América Latina. 2a edición. Monografía 13. OEA, Washington DC, 120 p.
Chébez, J.C. (2006). Guía de las Reservas Naturales de la Argentina: Zona Centro, 1ra Edición. Albatros, Buenos Aires, Vol. 5, 288 p.

Cherret, J.M. (1989). Leaf-cutting ants. In: Lieth, H., Werger, M. J. A. (Eds.), Tropical rainforest ecosystems: biogeographical and ecological studies (pp. 437-488). Elsevier Scientific Publishing Company, NY., USA.

Del Vitto, L.A., Petenatti, E.M., Nellar, M.M. \& Petenatti, M.E. (1994). Las Áreas Naturales Protegidas de San Luis, Argentina. Multequina 3: 141-156.

Diehl-Fleig, E. (1995). Formigas: organização social e ecología comportamental. São Leopoldo: Ed. UNISINOS, 166 p.

Farji-Brener, A.G. (2000). Leaf-cutting ant nests in temperate environments: mounds, mound damages and nest mortality rate in Acromyrmex lobicornis. Studies on Neotropical Fauna and Environment, 35: 131-138.

Farji-Brener, A.G. (2001). Why are leaf-cutting ants more common in early secondary forests than in old-growth tropical forests? An evaluation of the palatable forage hypothesis. Oikos, 92: 169-177. doi: 10.1034/j.1600-0706.2001.920120.x

Farji-Brener, A.G. \& Protomastro, J. (1992). Patrones forrajeros de dos especies simpátricas de hormigas cortadoras de hojas (Attini, Acromyrmex) en un bosque subtropical seco. Ecotrópicos, 5: 32-43.

Farji-Brener, A.G. \& Ruggiero A. (1994). Leaf-cutting ants (Atta and Acromyrmex) inhabiting Argentina: patterns in species richness and geographical range sizes. Journal of Biogeography, 21: 391-399. doi: 10.2307/2845757

Farji-Brener, A.G. \& Tadey, M. (2017). Consequences of leaf-cutting ants on plant fitness: integrating negative effects of herbivory and positive effects from soil improvement. Insectes Sociaux, 64: 45-54. doi: 10.1007/s00040-016-0510-2

Farji-Brener, A.G., de Torres Curth, M.I., Casanovas, P.V. \& Naim, P.N. (2003). Consecuencias demográficas del sitio de nidificación en la hormiga cortadora de hojas Acromyrmex lobicornis: un enfoque utilizando modelos matriciales. Ecología Austral, 13: 183-194.

Feinsinger, P.E., Spears, E. \& Poole, R. (1981). A simple measure of niche breadth. Ecology, 62: 27-32.

Fowler, H.G. (1977). Some factors influencing colony spacing and survival in the grass-cutting ant Acromyrmex landolti fracticornis (Forel) (Formicidae: Attini) in Paraguay. Revista de Biologia Tropical, 25: 89-99.

Franzel, C. \& Farji-Brener, A.G. (2000). ¿Oportunistas o selectivas? Plasticidad en la dieta de la hormiga cortadora de hojas Acromyrmex lobicornis en el noroeste de la Patagonia. Ecología Austral, 10: 159-168.

Hays, R.L., Summers, C. \& Seitz, W. (1981). Estimating wildlife habitat variables. USDI. Fish and wildlife service. FWS/OBS-81/47. Washington, USA. 111 p. 
Höldobler, B. \& Wilson, E.O. (1990). The ants. Cambridge: Harvard University Press, $732 \mathrm{p}$.

Hölldobler, B. \& Wilson, E.O. (2011). The leafcutter ants: civilization by instinct. Nueva York: W. W. Norton and Company, $160 \mathrm{p}$.

Ivlev, V.S. (1961). Experimental Ecology of the Feeding of fishes. New Heaven: Yale University Press, 302 p.

Jofré, L.E. \& Medina, A.I. (2012). Patrones de actividad forrajera y tamaño de nido de Acromyrmex lobicornis (Hymenoptera: Formicidae) en una zona urbana de San Luis, Argentina. Revista de la Sociedad Entomológica Argentina, 71: 37-44.

Kost, C., de Oliveira, E.G., Knoch, T.A. \& Wirth, R. (2005). Spatio-temporal permanence and plasticity of foraging trails in young and mature leaf-cutting ant colonies (Atta spp.). Journal of Tropical Ecology, 21: 677-688. doi: 10.1017/ S0266467405002592

Lanan, M. (2014). Spatiotemporal resource distribution and foraging strategies of ants (Hymenoptera: Formicidae). Myrmecological News, 20: 53-70.

Nichols-Orians, C.M. \& Schultz, J.C. (1990). Interactions among leaf toughness, chemistry, and harvesting by attine ants. Ecological Entomology, 15: 311-320. doi: 10.1111/ j.1365-2311.1990.tb00813.x

Nobua Behrmann, B.E. (2014). Interacciones tróficas entre dos especies simpátricas de hormigas cortadoras y el ensamble de plantas en el Monte central. PhD thesis, Universidad de Buenos Aires, Buenos Aires, Argentina, 117 p.

Nobua-Behrmann, B.E.; Lopez de Casenave, J.; Milesi, F.A. \& Farji-Brener, A. (2017). Coexisting in harsh environments: temperature-based foraging patterns of two desert leafcutter ants (Hymenoptera: Formicidae: Attini). Myrmecological News 25: 41-49

Pilati, A., Quirán, E.M. \& Estelrich, H.D. (1997). Actividad forrajera de Acromyrmex lobicornis Emery (Hymenoptera: Formicidae) en un pastizal natural semiárido de la provincia de La Pampa (Argentina). Ecología Austral, 7: 49-56.

R Core Team (2015). R: A language and environment for statistical computing. R Foundation for Statistical Computing, Vienna, Austria. URL https://www.R-project.org/.

Rockwood, L.L. \& Hubbell, S.P. (1987). Host-plant selection, diet diversity, and optimal foraging in a tropical leafcutting ant. Oecologia, 74: 55-61. doi: 10.1007/BF00377345

Stuble, K.L., Jurić, I., Cerdá, X. \& Sanders, N.J. (2017). Dominance hierarchies are a dominant paradigm in ant ecology (Hymenoptera: Formicidae), but should they be? And what is a dominance hierarchy anyways? Myrmecological News, 24: 71-81.

Vieira-Neto, E.H.M., Vasconcelos, H.L. \& Bruna, E.M. (2016). Roads increase population growth rates of a native leaf-cutter ant in Neotropical savannahs. Journal of Applied Ecology, 53: 983-992. doi: 10.1111/1365-2664.12651

Wetterer, J.K. (1994). Ontogenetic changes in forager polymorphism and foraging ecology in the leaf-cutting ant Atta cephalotes. Oecologia, 98: 235-238. doi: 10.1007/ BF00341478

Wirth, R., Herz, R., Ryel, R.J., Beyschlag, W. \& Hölldobler, B. (2003). Herbivory of leaf-cutting ants: a case study on Atta colombica in the tropical rainforest of Panama, Berlin: Springer Verlag, $230 \mathrm{p}$.

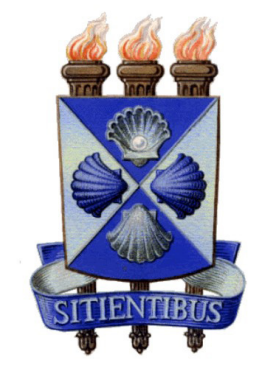

